\title{
The Effect of Financial Indicators on Trading Volume of the Listed Companies on the Tehran Stock Exchange
}

\author{
Farzaneh Nassirzadeh ${ }^{1}$, Mahdi Salehi ${ }^{2} \&$ Reza Sarvghadi $^{3}$ \\ ${ }^{1}$ Associate Professor of Accounting, Ferdowsi University of Mashhad, Mashhad, Iran \\ ${ }^{2}$ Assistant Professor of Accounting, Ferdowsi University of Mashhad, Mashhad, Iran \\ ${ }^{3}$ M.A. Student of Accounting, Ferdowsi University of Mashhad, Mashhad, Iran \\ Correspondence: Mahdi Salehi, Department of Accounting, Ferdowsi University of Mashhad, Mashhad, Iran. \\ E-mail: Mehdi.salehi@fum.ac
}

Received: March 4, 2015

Accepted: April 10, 2015

Online Published: April 25, 2015

doi:10.5539/ibr.v8n5p176

URL: http://dx.doi.org/10.5539/ibr.v8n5p176

\begin{abstract}
Millions of shares traded daily on the stock market. Factors influencing the number of transactions that will be remembered as the Trading Volume has been of interest to investors and analysts. The main source of information used for this purpose, is the company's financial indicators. The indicators include profitability ratios, liquidity ratios, debt ratios, efficiency ratios and stock market ratios.

The purpose of this study was to evaluate the effectiveness of the financial indicators on trading volume of 67 companies listed in Tehran Stock Exchange during the period 3/21/2010 to 3/20/2014. For this purpose, using Hierarchical Multiple Regression to examine each hypothesis, the relationship between the ratio and trading volume with control variables (year, industry, inflation and exchange rates) examined and on the basis of significance level was evaluated. Then on the basis of $\mathrm{R}^{2}$ factor in each group based on assumptions, most prominent were identified and selected on the end of an overall regression was performed.

The results indicate that liquidity and performance indicators are significantly related to trading volume. Also the results indicate that the most significant proportion of the working capital of a company that has the greatest impact on trading volume. In addition, the year, industry and exchange rates have a significant effect on the control variables, had a significant effect in the case of this study, then effect of them was controlled and eliminated.
\end{abstract}

Keywords: financial indicators, financial ratios, trading volume, hierarchical multiple regression, stock exchange

\section{Introduction}

Trading volume is a measure to determine the amount of financial assets are traded in a given time period. It is a very powerful tool, but too often it is a simple index, it is overlooked. Information from trading volume is observed easily from any source, but few traders and investors know how to use it to increase profits and minimize risk (Mitchell, 2014).

Several papers have been written about the trading activity in financial markets and different measures as trading volume is studied. Measures included: aggregate share volume, individual share volume, aggregate dollar volume, individual dollar volume, relative individual dollar volume, individual turnover, aggregate turnover, total number of trades, trading days per year and contracts traded (Lo \& Wang, 2000). Study trading volume due to his ties with other indicators of stock market is also important. So that in the stock markets of New York, London and Tokyo exist positive feedback relationship between trading volume and return volatility. The analysis show evidence of stronger spillover effects after the 1987 market crash and increased importance of trading volume as an information variable, especially after the introduction of options in the America and Japan (Lee \& Rui, 2002). Also, Reviews of ten East Asia stock markets Indicative the contemporaneous relation between stock returns and trading volume and the causal relation from stock returns and trading volume are significant and robust across all sample stock markets (Chuang, Liu, \& Susmel, 2012). There is also a correlation between the volatility of stock returns and trading volume (Park, 2010). Trading volume has some predictive power for high volume firms and in certain industries of the Australian market (Bissoondoyal-Bheenick \& 
Brooks, 2010).

Considering trading volume on the stock exchange how can be the impact of financial indicators on it? Used three bases for a comparative analysis of financial indicators:

Intracompany basis: This basis compares an item or financial relationship within a company in the current year with the same item or relationship in one or more prior years.

Industry averages: This basis compares an item or financial relationship of a company with industry averages published by financial ratings organizations.

Intercompany basis: This basis compares an item or financial relationship of one company with the same item or relationship in one or more competing companies.

Also commonly tools used to evaluate the significance of financial statement data are the following three categories:

Horizontal analysis evaluates a series of financial statement data over a period of time.

Vertical analysis evaluates financial statement data by expressing each item in a financial statement as a percent of a base amount.

Ratio analysis expresses the relationship among selected items of financial statement data (Weygandt, Kimmel, \& Kieso, 2010).

The definition and classification of financial ratios can be classified as follows:

Profitability ratios: This ratio indicates a company's ability to earn income.

Liquidity ratios: Measure the short-term ability of the company to pay its maturing obligations and to meet unexpected needs for cash.

Solvency ratios: Measure the ability of a company to survive over a long period of time.

Efficiency ratios: Measure of company performance, in terms of asset management.

Stock market ratio: Existing shareholders and potential investors in the stock exchange use common ratios for analyze and compare the profitability and return of large and small companies in various industries.

\section{Literature Review}

Ziebart (1987) modeled impact of unexpected changes in the financial dimensions to abnormal stock market returns and abnormal trading volume. To this end, thirteen financial ratios of the four group including liquidity, leverage, profitability and activity were selected. The results show that unexpected changes in the profitability ratios are main source of abnormal stock returns, but none of the unexpected changes in the financial dimensions that have a significant effect on abnormal trading volume and it indirectly affected by the abnormal returns.

Jahankhani and Saffarian (2004) studied profitability information content of per shares and the influence it on price and the trading volume in the Tehran stock exchange. The results of the test trading volume of 27 companies for the research period between 1996 to 1998 that the estimated earnings per share has been declared, in the 4 weeks before and 4 weeks after the announcement, expressive the content of the information and thus trading volume is changed. Although Tehran stock market reaction to the new data estimated with a delay.

Clark-Murphy and Soutar (2004) studied the Australian stock exchange and evaluated eleven financial factors influencing the decisions of individual investors, when buying shares. The results obtained suggest that the majority of individual investors have little interest in speculation and are, by nature, long-term investors. In deciding to buy a particular stock, financial measures, such as dividend and price-earnings ratio are relevant. However, they are less important than the company's management or recent movements in the share's price. The relative importance of each of the factors affecting the company's trading volume in the Australian stock exchange as follows:

1- Management, 2- Market Status, 3- Price Trend, 4- Source of Recommendation, 5- Principal Place of Operation, 6- Dividend 7- Price Earnings Ratio, 8- Yield, 9- Industry Sector, 10- Price Volatility 11- Knowledge Base.

Shooshtarian and Akbari (2008) examined the impact of the capital increase from the Preference to trading volume. The results showed that exist a significant relationship between the announcement of the capital increase from the Preference and trading volume changes. So that declined the average of trading volume in the declaration week, and declined sharply in the first week after the announcement again. After that, the growing trading volume, correct the previous motion Partly, However, compared with the pre-announced an increase of 
capital, trading volume is lower. The other finding of this study is that there is no significant relationship between the type of industry and changes in trading volume caused by the announcement of the capital increase from the Preference.

Chu and Ip (2007) analyzed company Information effectiveness on the short selling trading volume in the Hong Kong stock market. They found that the financial ratios namely quick ratio, price-to-book ratio, time interest ratio, inventory turnover and earnings per share have an inversely proportion to the number of short selling in the market. Meanwhile, the ratios including ROA and price-to-sales ratio have a positive relation to the number of short selling. Short sellers may also refer to factors like changing in directorship and company news (dummy variables) in making their investment decision.

Khoshtinat and Hajian (2009) examined the effect of dividend increases on the Tehran Stock Exchange trading volume. Using Mean comparison with a constant value test, correlation and regression analysis, the results show that increasing dividends effect on trading volume. In other words, trading volume increased after the announcement of dividend increases. Also the reaction of investors to the dividend increase is short-term reaction. This means that there is a very little direct relationship between the percentage of dividend increases and the percentage changes in trading volume in the short term but there is no relationship in long term.

Gopalan, Kadan, and Pevzner (2009) studied relationship between liquidity of the firm's assets and liquidity of stock. This relationship depends on market expectations regarding the deployment of the firm's liquid assets. They found that after controlling for firm fixed effects, a one standard deviation increase in asset liquidity increases stock liquidity by $14.5 \%$. The relation is stronger when the manager is less likely to convert liquid assets into illiquid assets such as for low market to book and low capital expenditure firms, during economic recessions, and when expected payout is high. Apart from linking corporate finance decisions to stock liquidity, the analysis also promotes a new rationale for several empirical regularities such as the commonality in stock liquidity and the improvement in stock liquidity following equity issuances.

Raee, Saranj, and Sadeghi (2011) Studied on EPS as reference point investment decision and its relationship with trading volume. They found that trading volume are more affected by positive and negative adjustment EPS. As adjusted EPS, trading volume increased.

Rahmani, Hoseini, and Rezapur (2011) defined twelve of Trading different measures for liquidity as the dependent variable. Meanwhile, the book value to market value ratio has a significant relationship with some measures of liquidity Including trading share volume, the number of trades and the trading waiting. Also that has not a significant relationship with some other measures of liquidity including trading Dollar volume, trading days per year and trading share turnover.

Talebnia and Zarey (2011) studied the impact of financial factors on trading volume on the Tehran Stock Exchange. The first phase of that study, the relationship of each financial variable was examined with trading volume. Correlation and linear regression were used for this purpose. EPS, Dividend rate and Liquidity Rating had the highest correlation with trading volume. Secondly, by using backward regression, found influential financial variables on firms' trading volume that they were. EPS, Risk stocks in the previous year and P/E.

Purebrahimi and Seyedkhosroshahi (2013) investigated the relationship between trading volume (including free float as a measure of liquidity) and the rate of dividend payment (by controlling firm characteristics, including size, profitability and growth opportunities). The results showed that there was negative correlation between the amount of dividends and trading volume, but did not show evidence to confirm the relationship between these two variables.

Firoozi, Hemmati, and Ghodrati (2013) examined the relationship between measures of asset liquidity and trading volume turnover. They also used three control variables, including the market value of equity to book value of equity ratio (indicator of growth opportunities business unit), dividends to net income ratio (indicator of management decisions on the payment of dividends) logarithm of the market value of equity (indicator of the business unit size). The results showed that there is a significant relationship between the liquidity of assets and trading volume turnover. After controlling for fixed effects of business unit, an increase in the liquidity of assets, increases trading volume turnover.

$$
a^{2}+b^{2}=c^{2}
$$

\section{Research Methodology}

Our sample consists of 67 companies listed on the Tehran Stock Exchange during the period 3/21/2010 to 3/20/2014. They have the following conditions: 
1) They adopted Tehran Stock Exchange By the end of 3/20/2010 and their financial year ending are in March-20 each year.

2) The company's financial year shall not be changed during the period in question.

3) Companies during the period of this study have continuous activity and their Trading symbol have not stopped more than two months.

4) They are not investment firms, banks and financial intermediation. Done with restrictions, we elected 335 years- company.

Selected samples of the population are from 18 different industries.

\subsection{Hypotheses}

$\mathrm{H}_{1}$ : Firm's profitability indicators have significant correlation on firm's trading volume.

$\mathrm{H}_{1 \mathrm{a}}$ : Firm's net margin ratio has significant correlation on firm's trading volume.

$\mathrm{H}_{1 \mathrm{~b}}$ : Firm's operating margin ratio has significant correlation on firm's trading volume.

$\mathrm{H}_{1 \mathrm{c}}$ : Firm's return on assets has significant correlation on firm's trading volume.

$\mathrm{H}_{1 \mathrm{~d}}$ : Firm's return on equity has significant correlation on firm's trading volume.

$\mathrm{H}_{2}$ : Firm's liquidity indicators have significant correlation on firm's trading volume.

$\mathrm{H}_{2 \mathrm{a}}$ : Firm's current ratio has significant correlation on firm's trading volume.

$\mathrm{H}_{2 \mathrm{~b}}$ : Firm's quick ratio has significant correlation on firm's trading volume.

$\mathrm{H}_{2 \mathrm{c}}$ : Firm's working capital has significant correlation on firm's trading volume.

$\mathrm{H}_{2 \mathrm{~d}}$ : Firm's operating cash flow has significant correlation on firm's trading volume.

$\mathrm{H}_{3}$ : Firm's solvency indicators have significant correlation on firm's trading volume.

$\mathrm{H}_{3 \mathrm{a}}$ : Firm's debt to assets ratio has significant correlation on firm's trading volume.

$\mathrm{H}_{3 \mathrm{~b}}$ : Firm's debt to equity ratio has significant correlation on firm's trading volume.

$\mathrm{H}_{3 \mathrm{c}}$ : Firm's plant assets to long-term liabilities ratio has significant correlation on firm's trading volume.

$\mathrm{H}_{3 \mathrm{~d}}$ : Firm's cash flow to total debt has significant correlation on firm's trading volume.

$\mathrm{H}_{3 \mathrm{e}}$ : Firm's equity financing ratio has significant correlation on firm's trading volume.

\subsection{Data and Data Sources}

The dependent variable is Trading Volume, which equal to the number of shares traded during the year.

The independent variables in this research are financial indicators, which measured as follows:

\subsection{Profitability Indicators}

1) Net margin $=$ Net income $\div$ Net sales or Total revenue.

2) Operating margin $=$ Net operating profit $\div$ Net sales or Total revenue.

3) Return on assets $=$ Net income $\div$ Total assets.

4) Return on equity $=$ Net income $\div$ Total stockholders' equity.

\subsection{Liquidity Indicators}

1) Current ratio $=$ Current assets $\div$ Current liabilities.

2) Quick ratio $=($ Current assets - Inventory - Prepaid $) \div$ Current liabilities.

3) Working capital $=$ Current assets - Current liabilities.

4) Operating cash flow $=$ Cash flow related to operations $\div$ Current liabilities.

\subsection{Solvency Indicators}

1) Debt to assets $=$ Total liabilities $\div$ Total assets.

2) Debt to equity $=$ Total liabilities $\div$ Total stockholders' equity.

3) Plant assets to long-term liabilities $=$ Net plant assets $\div$ Long-term liabilities.

4) Cash flow to total debt $=$ cash flow related to operations $\div$ Total liabilities. 
5) Equity financing ratio $=$ Total stockholders' equity $\div$ Total assets.

\subsection{Efficiency Indicators}

1) Total asset turnover $=$ Sales or Total operating revenue $\div$ Average Total asset.

2) Fixed asset turnover $=$ Sales or Total operating revenue $\div$ Net fixed asset.

3) Current asset turnover $=$ Sales or Total operating revenue $\div$ Current asset.

4) Working capital turnover $=$ Sales or Total operating revenue $\div$ Working Capital.

\subsection{Stock Market Indicators}

1) Earnings per share $=$ Net earnings available for common stock $\div$ outstanding common shares.

2) Book value per share $=$ (Stockholders' equity - Preferred rights $\div$ Outstanding common shares.

3) Price-earnings $=$ Market price per share $\div$ Earnings per share.

4) Dividend yield $=$ Dividends per share $\div$ Average market price per share.

Also the four non-financial variables (inflation rates, exchange rates, industry effect and year effect) have been chosen as control variables and their effects are eliminated.

The research data has been extracted from financial statements of listed companies on the Tehran Stock Exchange and the Central Bank of the Islamic Republic of Iran.

\section{Hypotheses Testing}

After selecting the variables and data collection, were calculated descriptive statistics with SPSS8 for the variables used in this study during the period of study for sample companies (335 year-company) and are presented in Table 1.

Table 1. Descriptive statistics of variables

\begin{tabular}{|c|c|c|c|c|c|}
\hline Variables & No. & Min & Max & Mean & S.d \\
\hline Trading volume & 335 & 263,612 & $5,435,519,537$ & $160,000,000$ & $566,000,000$ \\
\hline Net margin & 335 & -0.2599 & 1.0463 & 0.2104 & 0.1900 \\
\hline Operating margin & 335 & -0.2075 & 0.9683 & 0.2437 & 0.1740 \\
\hline Return on assets & 335 & -0.1406 & 0.6313 & 0.1378 & 0.1049 \\
\hline Return on equity & 335 & -0.0678 & 2.8129 & 0.3002 & 0.3988 \\
\hline Current ratio & 335 & 0.2226 & 5.1214 & 1.3880 & 0.6820 \\
\hline Quick ratio & 335 & 0.0576 & 4.4661 & 0.7952 & 0.4940 \\
\hline Working capital & 335 & -324777 & 15525992 & 306668.12 & 1397856.158 \\
\hline Operating cash flow & 335 & -0.4726 & 2.7739 & 0.3203 & 0.3909 \\
\hline Debt to assets ratio & 335 & 0.1109 & 1.0537 & 0.5846 & 0.1861 \\
\hline Debt to equity ratio & 335 & -628.502 & 26.2723 & -0.4445 & 34.8739 \\
\hline Plant assets to long-term liabilities & 325 & 0.1293 & 1712.2037 & 12.3514 & 95.3082 \\
\hline Cash flow to total debt & 335 & -0.4339 & 2.5851 & 0.2737 & 0.3420 \\
\hline equity financing ratio & 335 & -0.0537 & 0.8891 & 0.4156 & 0.1862 \\
\hline Total asset turnover & 335 & 0.0590 & 3.0469 & 0.8641 & 0.4371 \\
\hline Fixed asset turnover & 335 & 0.3708 & 58.4704 & 6.0314 & 5.9142 \\
\hline Current asset turnover & 335 & 0.0727 & 4.4280 & 1.3532 & 0.7068 \\
\hline Working capital turnover & 335 & -781.731 & 755.3888 & 2.9536 & 79.4784 \\
\hline Earnings per share & 335 & -1131 & 7988 & 956.12 & 1083.696 \\
\hline Book value per share & 335 & -322.79 & 10409.16 & 2520.2329 & 1516.7127 \\
\hline Price-earnings ratio & 335 & -31.1578 & 376.4178 & 10.3231 & 30.6574 \\
\hline Dividend yield & 335 & 0 & 1.3130 & 0.1302 & 0.1194 \\
\hline inflation rate (Percent) & 335 & 10.8 & 34.7 & 21.98 & 9.5157 \\
\hline exchange rate (Rials) & 335 & 9979 & 31838 & 18076.8 & 9108.8 \\
\hline
\end{tabular}


The hypothesis of this research with using the collected data analyzed by Hierarchical Multiple Regression was tested as follows. Since, there is a correlation between components of each of the hypotheses of the study, the preconditions is not established for the use of multiple regression. So we cannot analysis all ratios to a multiple regression. Hence, to examine each of the hypotheses used in the multiple regression and are examined relationship between the ratio and trading volume with the control variable (Hierarchical multiple regression); and then evaluated based on their level of significance. Then, based on the coefficient of determination $\left(\mathrm{R}^{2}\right)$ in each group of the hypotheses, and identify the most significant and finally on them, a general regression is done. Essential preconditions in the regression model, as follows which is required before performing any regression, check the validity of the assumptions:

1) Assess the normality of residuals: Kolmogorov-Smirnov test was used for this purpose. If the probability of this case is larger than 0.05 , normality of residuals are approved by $95 \%$.

2) Check non- autocorrelation in the residuals: Durbin-Watson test was used for this purpose. If the Durbin-Watson statistic is close to 2, the independence of residuals will be accepted.

3) Determine residual variances consistency: for this purpose we will use the scatter plot of standardized residual versus standardized predicated value. There symmetric around the zero line, and absence trend in the graph represents the residual variance is homogeneous.

4) Check multicollinearity between the independent variables: we use VIF and Tolerance tests for this purpose. This means that if VIF was less than 10 and Tolerance was greater than 1.0, the problem of multicollinearity between the independent variables is not observed in the model.

The first, preconditions regression was performed, and due to the lack establish of normality of residuals preconditions, the logarithmic conversion (lny) was used for the dependent variable. Hierarchical multiple regression model used to test the hypotheses following:

$$
\operatorname{LnY}=\beta_{0}+\beta_{1} X+\beta_{2 i} C_{1 i}+\beta_{3 j} C_{2 j}+\beta_{4} C_{3}+\beta_{5} C_{4}+\varepsilon
$$

LnY: Logarithm of trading volume (number of shares traded);

$\mathrm{X}_{\mathrm{i}}$ : The ratio the study in each of the hypotheses;

$\mathrm{C}_{1 \mathrm{i}}$ : Control variable of year effect of $\mathrm{i}(\mathrm{i}=1,2,3,4)$ which takes only two values, zero or one;

$\mathrm{C}_{2}$ : Control variable of Industry effect of $\mathrm{i}(\mathrm{i}=1,2,3,4,5)$ which takes only two values, zero or one;

$\mathrm{C}_{3}$ : Control variable of inflation rate;

$\mathrm{C}_{4}$ : Control variable of exchange rate;

4.1 The First Hypothesis Testing $\left(H_{1}\right)$

This hypothesis includes the 4 Secondary hypotheses. First, we test the Secondary hypothesises and then final conclusions expressed based on the results. Hierarchical multiple regression results are shown in the following tables.

Table 2. Hierarchical multiple regression model coefficients for $\mathrm{H}_{1 \mathrm{a}}$

\begin{tabular}{|c|c|c|c|c|c|c|}
\hline \multirow[b]{2}{*}{ Variable } & \multicolumn{2}{|c|}{ Coefficient of $\beta$} & \multirow[b]{2}{*}{ T-statistics } & \multirow[b]{2}{*}{ P-value } & \multicolumn{2}{|c|}{ Collinearity Statistics } \\
\hline & Non-standard & Standard & & & Tolerance & VIF \\
\hline Constant value & 14.904 & --- & 39.919 & 0.000 & --- & --- \\
\hline Net margin & 1.343 & 0.134 & 2.55 & $* 0.011$ & 0.82 & 1.22 \\
\hline Year 1 & 0.013 & 0.037 & 0.782 & 0.556 & 0.18 & 1.59 \\
\hline Year 2 & 0.494 & 0.104 & 1.743 & 0.082 & 0.64 & 1.57 \\
\hline Year 3 & 0.612 & 0.129 & 2.238 & $* 0.026$ & 0.68 & 1.46 \\
\hline Year 4 & -0.593 & -0.125 & -2.309 & $* 0.022$ & 0.78 & 1.29 \\
\hline Industry 1 & 0.296 & 0.056 & 0.932 & 0.352 & 0.64 & 1.56 \\
\hline Industry 2 & -0.624 & -0.148 & -2.278 & $* 0.023$ & 0.54 & 1.86 \\
\hline Industry 3 & -1.298 & -0.162 & -2.957 & $* 0.003$ & 0.76 & 1.32 \\
\hline Industry 4 & 1.028 & 0.201 & 3.235 & $* 0.001$ & 0.59 & 1.69 \\
\hline Industry 5 & 0.82 & 0.16 & 2.638 & $* 0.009$ & 0.62 & 1.62 \\
\hline
\end{tabular}




\begin{tabular}{|c|c|c|c|c|c|c|}
\hline Inflation rate & -0.022 & -0.041 & -0.213 & 0.451 & 0.63 & 1.46 \\
\hline Exchange rate & 0.00007 & 0.374 & 5.948 & $* 0.000$ & 0.57 & 1.74 \\
\hline DW & & 1.744 & & Sig & \multicolumn{2}{|c|}{$* 0.000$} \\
\hline KS & & 0.296 & & F statistics & \multicolumn{2}{|c|}{11.611} \\
\hline
\end{tabular}

Note. * Significant at the $5 \%$ level.

According to Table 2, it is observed that the significance level of model is 0.000 and less than 0.05 , so the model is significant. The regression model is as follows:

$$
\begin{gathered}
\operatorname{Ln} Y=14.904+1.343 X+0.013 C_{1.1}+0.494 C_{1.2}+0.612 C_{1.3}-0.593 C_{1.4}+0.296 C_{2.1}-0.624 C_{2.2} \\
-1.298 C_{2.3}+1.028 C_{2.4}+0.82 C_{2.5}-0.022 C_{3}+0.00007 C_{4}
\end{gathered}
$$

The results in Table 2 show that significant level of net margin variable is equal to 0.011 and less than 0.05 . So, the null hypothesis was rejected with $95 \%$ confidence $(\mathrm{Sig}=0.011<0.05)$ and can be said Firm's net margin ratio has significant correlation on firm's trading volume. Due to the positive coefficient on net margin, we can say that kind of relationship is positive and direct. Assuming a constant other variables in the regression model, and the elimination of the control variables, each unit increase in net income resulted 1.343 unit increases in the company's trading volume. Also, about the control variables, the industry $2,3,4 \& 5$, the year $3 \& 4$ and exchange rate are statistically significant $(\mathrm{Sig}<0.05)$, that their effects was controlled and eliminated. Therefore, the research hypothesis $1 \mathrm{a}$ is confirmed.

Table 3. Results of hierarchical multiple regression model for $\mathrm{H}_{1 \mathrm{a}}$

\begin{tabular}{lcc}
\hline Model & $\mathrm{R}^{2}$ & $\Delta \mathrm{R}^{2}$ \\
\hline Model 1 (including control variables) & 0.249 & 0.249 \\
Model 2 (including all independent and control variables) & 0.264 & 0.015 \\
\hline
\end{tabular}

According to Table 3, it becomes clear after elimination of control variables, net margin express of about 0.015 of changes in the company's trading volume.

\begin{tabular}{|c|c|c|c|c|c|c|}
\hline \multirow[b]{2}{*}{ Variable } & \multicolumn{2}{|c|}{ Coefficient of $\beta$} & \multirow[b]{2}{*}{ T-statistics } & \multirow[b]{2}{*}{ P-value } & \multicolumn{2}{|c|}{ Collinearity Statistics } \\
\hline & Non-standard & Standard & & & Tolerance & VIF \\
\hline Constant value & 14.986 & --- & 39.223 & 0.000 & --- & --- \\
\hline Operating margin & 0.714 & 0.065 & 1.186 & 0.236 & 0.76 & 1.31 \\
\hline Year 1 & 0.28 & 0.21 & 1.004 & 0.085 & 0.56 & 1.23 \\
\hline Year 2 & 0.52 & 0.11 & 1.822 & 0.069 & 0.64 & 1.57 \\
\hline Year 3 & 0.633 & 0.133 & 2.294 & $* 0.022$ & 0.68 & 1.47 \\
\hline Year 4 & -0.584 & -0.123 & -2.256 & $* 0.025$ & 0.78 & 1.29 \\
\hline Industry 1 & 0.273 & 0.051 & 0.843 & 0.400 & 0.63 & 1.59 \\
\hline Industry 2 & -0.635 & -0.151 & -2.265 & $* 0.024$ & 0.52 & 1.92 \\
\hline Industry 3 & -1.443 & -0.18 & -3.273 & $* 0.001$ & 0.76 & 1.31 \\
\hline Industry 4 & 1.103 & 0.215 & 3.386 & $* 0.001$ & 0.57 & 1.75 \\
\hline Industry 5 & 0.77 & 0.15 & 2.462 & $* 0.014$ & 0.62 & 1.62 \\
\hline Inflation rate & -0.016 & -0.035 & -0.415 & 0.321 & 0.68 & 1.69 \\
\hline Exchange rate & 0.000079 & 0.382 & 6.02 & $* 0.000$ & 0.58 & 1.74 \\
\hline DW & & 1.728 & & Sig & & \\
\hline $\mathrm{KS}$ & & 0.237 & & F statistics & & \\
\hline
\end{tabular}

Table 4. Hierarchical multiple regression model coefficients for $\mathrm{H}_{1 \mathrm{~b}}$

Note. * Significant at the $5 \%$ level. 
According to Table 4 , it is observed that the significance level of model is 0.000 and less than 0.05 , so the model is significant. The regression model is as follows:

$$
\begin{gathered}
\operatorname{Ln} Y=14.986+0.714 X+0.28 C_{1.1}+0.52 C_{1.2}+0.633 C_{1.3}-0.584 C_{1.4}+0.273 C_{2.1}-0.635 C_{2.2} \\
-1.443 C_{2.3}+1.103 C_{2.4}+0.77 C_{2.5}-0.016 C_{3}+0.000079 C_{4}
\end{gathered}
$$

The results in Table 4 show that significant level of Operating margin variable is equal to 0.236 and more than 0.05 . So, the null hypothesis was not rejected with $95 \%$ confidence $(\mathrm{Sig}=0.236>0.05)$ and can be said there is no significant correlation between firm's operating margin and firm's trading volume. Also, about the control variables, the industry $2,3,4 \& 5$, the year $3 \& 4$ and exchange rate are statistically significant $(\operatorname{Sig}<0.05)$, that their effects was controlled and eliminated. Therefore, the research hypothesis $1 \mathrm{~b}$ is not confirmed.

Table 5. Results of hierarchical multiple regression model for $\mathrm{H}_{1 \mathrm{~b}}$

\begin{tabular}{lcc}
\hline Model & $\mathrm{R}^{2}$ & $\Delta \mathrm{R}^{2}$ \\
\hline Model 1 (including control variables) & 0.249 & 0.249 \\
Model 2 (including all independent and control variables) & 0.252 & 0.003 \\
\hline
\end{tabular}

According to Table 5, it becomes clear after elimination of control variables, operating margin express of about 0.003 of changes in the company's trading volume.

Table 6. Hierarchical multiple regression model coefficients for $\mathrm{H}_{1 \mathrm{c}}$

\begin{tabular}{lcccccc}
\hline & \multicolumn{2}{c}{ Coefficient of $\beta$} & & & \multicolumn{2}{c}{ Collinearity Statistics } \\
\cline { 2 - 3 } Variable & Non-standard & Standard & T-statistics & P-value & Tolerance & VIF \\
\hline Constant value & 15.198 & -- & 40.471 & 0.000 & -- & -- \\
Return on assets & -1.154 & -0.064 & -1.140 & 0.255 & 0.74 & 1.35 \\
Year 1 & 0.271 & 0.203 & 1.302 & 0.091 & 0.54 & 1.46 \\
Year 2 & 0.532 & 0.112 & 1.862 & 0.063 & 0.64 & 1.57 \\
Year 3 & 0.63 & 0.133 & 2.283 & $* 0.023$ & 0.68 & 1.46 \\
Year 4 & -0.587 & -0.124 & -2.267 & $* 0.024$ & 0.78 & 1.29 \\
Industry 1 & 0.353 & 0.066 & 1.1 & 0.272 & 0.64 & 1.57 \\
Industry 2 & -0.499 & -0.118 & -1.765 & 0.079 & 0.51 & 1.95 \\
Industry 3 & -1.639 & -0.205 & -3.745 & $* 0.000$ & 0.77 & 1.29 \\
Industry 4 & 1.328 & 0.259 & 4.060 & $* 0.000$ & 0.57 & 1.76 \\
Industry 5 & 0.691 & 0.135 & 2.201 & $* 0.028$ & 0.62 & 1.63 \\
Inflation rate & -0.018 & -0.038 & -0.510 & 0.309 & 0.63 & 1.81 \\
Exchange rate & 0.00008 & 0.397 & 6.216 & $* 0.000$ & 0.57 & 1.76 \\
\hline DW & & 1.720 & & Sig & & $* 0.000$ \\
KS & 0.177 & & F statistics & & 10.918
\end{tabular}

Note. * Significant at the $5 \%$ level.

According to Table 6, it is observed that the significance level of model is 0.000 and less than 0.05 , so the model is significant. The regression model is as follows:

$$
\begin{gathered}
\operatorname{Ln} Y=14.198-1.154 X+0.271 C_{1.1}+0.532 C_{1.2}+0.63 C_{1.3}-0.587 C_{1.4}+0.353 C_{2.1}-0.499 C_{2.2} \\
-1.639 C_{2.3}+1.328 C_{2.4}+0.691 C_{2.5}-0.018 C_{3}+0.00008 C_{4}
\end{gathered}
$$

The results in Table 6 show that significant level of Return on assets variable is equal to 0.255 and more than 0.05 . So, the null hypothesis was not rejected with $95 \%$ confidence $(\mathrm{Sig}=0.255>0.05)$ and can be said there is no significant correlation between firm's return on assets and firm's trading volume. Also, about the control 
variables, the industry $3,4 \& 5$, the year $3 \& 4$ and exchange rate are statistically significant $(\operatorname{Sig}<0.05)$, that their effects was controlled and eliminated. Therefore, the research hypothesis $1 \mathrm{c}$ is not confirmed.

Table 7. Results of hierarchical multiple regression model for $\mathrm{H}_{1 \mathrm{c}}$

\begin{tabular}{lcc}
\hline Model & $\mathrm{R}^{2}$ & $\Delta \mathrm{R}^{2}$ \\
\hline Model 1 (including control variables) & 0.249 & 0.249 \\
Model 2 (including all independent and control variables) & 0.252 & 0.003 \\
\hline
\end{tabular}

According to Table 7, it becomes clear after elimination of control variables, return on assets express of about 0.003 of changes in the company's trading volume.

Table 8. Hierarchical multiple regression model coefficients for $\mathrm{H}_{1 \mathrm{~d}}$

\begin{tabular}{lcccccc}
\hline \multirow{2}{*}{ Variable } & \multicolumn{2}{c}{ Coefficient of $\beta$} & \multirow{2}{*}{ T-statistics } & P-value & \multicolumn{2}{c}{ Collinearity Statistics } \\
\cline { 2 - 3 } Constant value & Non-standard & Standard & & Tolerance & VIF \\
Return on equity & 15.141 & --- & 40.292 & 0.000 & -- & --- \\
Year 1 & -0.1 & -0.021 & -0.413 & 0.680 & 0.89 & 1.12 \\
Year 2 & 0.246 & 0.214 & 0.694 & 0.142 & 0.55 & 1.35 \\
Year 3 & 0.512 & 0.108 & 1.788 & 0.075 & 0.64 & 1.57 \\
Year 4 & 0.618 & 0.13 & 2.237 & $* 0.026$ & 0.68 & 1.46 \\
Industry 1 & -0.591 & -0.125 & -2.275 & $* 0.024$ & 0.77 & 1.29 \\
Industry 2 & 0.321 & 0.06 & 1.002 & 0.317 & 0.64 & 1.57 \\
Industry 3 & -0.556 & -0.132 & -1.997 & $* 0.047$ & 0.53 & 1.89 \\
Industry 4 & -1.58 & -0.197 & -3.617 & $* 0.000$ & 0.78 & 1.28 \\
Industry 5 & 1.219 & 0.238 & 3.903 & $* 0.000$ & 0.62 & 1.60 \\
Inflation rate & 0.722 & 0.141 & 2.297 & $* 0.022$ & 0.62 & 1.62 \\
Exchange rate & -0.015 & -0.033 & -0.890 & 0.214 & 0.66 & 1.83 \\
\hline DW & 0.00008 & 0.387 & 6.116 & $* 0.000$ & 0.58 & 1.73 \\
KS & & 1.723 & & Sig & & $* 0.000$ \\
\hline
\end{tabular}

Note. * Significant at the $5 \%$ level.

According to Table 8 , it is observed that the significance level of model is 0.000 and less than 0.05 , so the model is significant. The regression model is as follows:

$$
\begin{gathered}
\operatorname{Ln} Y=15.141-0.1 X+0.246 C_{1.1}+0.512 C_{1.2}+0.618 C_{1.3}-0.591 C_{1.4}+0.321 C_{2.1}-0.556 C_{2.2} \\
-1.58 C_{2.3}+1.219 C_{2.4}+0.722 C_{2.5}-0.015 C_{3}+0.00008 C_{4}
\end{gathered}
$$

The results in Table 8 show that significant level of Return on equity variable is equal to 0.68 and more than 0.05 . So, the null hypothesis was not rejected with $95 \%$ confidence ( $\mathrm{Sig}=0.68>0.05)$ and can be said there is no significant correlation between firm's return on equity and firm's trading volume. Also, about the control variables, the industry $2,3,4 \& 5$, the year $3 \& 4$ and exchange rate are statistically significant $(\operatorname{Sig}<0.05)$, that their effects was controlled and eliminated. Therefore, the research hypothesis $1 \mathrm{~d}$ is not confirmed.

Table 9. Results of hierarchical multiple regression model for $\mathrm{H}_{1 \mathrm{~d}}$

\begin{tabular}{lcc}
\hline Model & $\mathrm{R}^{2}$ & $\Delta \mathrm{R}^{2}$ \\
\hline Model 1 (including control variables) & 0.249 & 0.249 \\
Model 2 (including all independent and control variables) & 0.2494 & 0.0004 \\
\hline
\end{tabular}


According to Table 9, it becomes clear after elimination of control variables, return on equity express of about 0.0004 of changes in the company's trading volume.

Consequently, according to the results of hypothesis testing, it was determined that only Net margin has a significant relationship with trading volume.

\subsection{The Second Hypothesis Testing $\left(H_{2}\right)$}

This hypothesis includes the 4 Secondary hypotheses. First, we test the Secondary hypothesises and then final conclusions expressed based on the results. Hierarchical multiple regression results are shown in the following tables.

Table 10. Hierarchical multiple regression model coefficients for $\mathrm{H}_{2 \mathrm{a}}$

\begin{tabular}{lcccccc}
\hline \multirow{2}{*}{ Variable } & \multicolumn{2}{c}{ Coefficient of $\beta$} & \multirow{2}{*}{ T-statistics } & P-value & \multicolumn{2}{c}{ Collinearity Statistics } \\
\cline { 2 - 3 } & Non-standard & Standard & & Tolerance & VIF \\
\hline Constant value & 15.54 & --- & 37.413 & 0.000 & -- & -- \\
Current ratio & -0.329 & -0.118 & -2.180 & $* 0.030$ & 0.78 & 1.28 \\
Year 1 & 0.282 & 0.209 & 0.591 & 0.203 & 0.60 & 1.42 \\
Year 2 & 0.545 & 0.115 & 1.917 & 0.056 & 0.64 & 1.57 \\
Year 3 & 0.659 & 0.139 & 2.399 & $* 0.017$ & 0.68 & 1.47 \\
Year 4 & -0.598 & -0.126 & -2.319 & $* 0.021$ & 0.78 & 1.29 \\
Industry 1 & 0.101 & 0.019 & 0.300 & 0.764 & 0.58 & 1.73 \\
Industry 2 & -0.652 & -0.155 & -2.359 & $* 0.019$ & 0.53 & 1.88 \\
Industry 3 & -1.717 & -0.214 & -3.943 & $* 0.000$ & 0.77 & 1.29 \\
Industry 4 & 1.317 & 0.257 & 4.201 & $* 0.000$ & 0.61 & 1.64 \\
Industry 5 & 0.651 & 0.127 & 2.085 & $* 0.038$ & 0.62 & 1.63 \\
Inflation rate & -0.031 & -0.037 & -0.991 & 0.321 & 0.73 & 1.99 \\
Exchange rate & 0.000085 & 0.408 & 6.412 & $* 0.000$ & 0.56 & 1.77 \\
\hline DW & & 1.715 & & Sig & & $* 0.000$ \\
KS & 0.343 & & F statistics & 11.377
\end{tabular}

Note. * Significant at the $5 \%$ level.

According to Table 10, it is observed that the significance level of model is 0.000 and less than 0.05 , so the model is significant. The regression model is as follows:

$$
\begin{gathered}
\operatorname{LnY}=15.54-0.329 X+0.282 C_{1.1}+0.545 C_{1.2}+0.659 C_{1.3}-0.598 C_{1.4}+0.101 C_{2.1}-0.652 C_{2.2} \\
-1.717 C_{2.3}+1.317 C_{2.4}+0.651 C_{2.5}-0.031 C_{3}+0.000085 C_{4}
\end{gathered}
$$

The results in Table 10 show that significant level of current ratio variable is equal to 0.030 and less than 0.05 . So, the null hypothesis was rejected with $95 \%$ confidence $(\mathrm{Sig}=0.030<0.05)$ and can be said Firm's current ratio has significant correlation on firm's trading volume. Due to the negative coefficient on current ratio, we can say that kind of relationship is negative and reverse. Assuming a constant other variables in the regression model, and the elimination of the control variables, each unit increase in current ratio resulted 0.329 unit decreases in the company's trading volume. Also, about the control variables, the industry $2,3,4 \& 5$, the year $3 \& 4$ and exchange rate are statistically significant $(\mathrm{Sig}<0.05)$, that their effects was controlled and eliminated. Therefore, the research hypothesis $2 \mathrm{a}$ is confirmed.

Table 11. Results of hierarchical multiple regression model for $\mathrm{H}_{2 a}$

\begin{tabular}{lcc}
\hline Model & $\mathrm{R}^{2}$ & $\Delta \mathrm{R}^{2}$ \\
\hline Model 1 (including control variables) & 0.249 & 0.249 \\
Model 2 (including all independent and control variables) & 0.260 & 0.011 \\
\hline
\end{tabular}


According to Table 11, it becomes clear after elimination of control variables, current ratio express of about 0.011 of changes in the company's trading volume.

Table 12. Hierarchical multiple regression model coefficients for $\mathrm{H}_{2 b}$

\begin{tabular}{lcccccc}
\hline \multirow{2}{*}{ Variable } & \multicolumn{2}{c}{ Coefficient of $\beta$} & \multirow{2}{*}{ T-statistics } & P-value & \multicolumn{2}{c}{ Collinearity Statistics } \\
\cline { 2 - 3 } Constant value & Non-standard & Standard & & Tolerance & VIF \\
Quick ratio & 14.908 & -- & 37.226 & 0.000 & -- & -- \\
Year 1 & 0.262 & 0.068 & 1.262 & 0.208 & 0.79 & 1.26 \\
Year 2 & 0.572 & 0.218 & 1.005 & 0.061 & 0.57 & 1.22 \\
Year 3 & 0.51 & 0.107 & 1.787 & 0.075 & 0.64 & 1.57 \\
Year 4 & 0.612 & 0.129 & 2.219 & $* 0.027$ & 0.68 & 1.46 \\
Industry 1 & -0.569 & -0.12 & -2.197 & $* 0.029$ & 0.77 & 1.29 \\
Industry 2 & 0.45 & 0.085 & 1.349 & 0.178 & 0.59 & 1.70 \\
Industry 3 & -0.58 & -0.138 & -2.109 & $* 0.036$ & 0.54 & 1.85 \\
Industry 4 & -1.485 & -0.185 & -3.420 & $* 0.001$ & 0.79 & 1.27 \\
Industry 5 & 1.146 & 0.224 & 3.623 & $* 0.000$ & 0.61 & 1.65 \\
Inflation rate & 0.782 & 0.153 & 2.494 & $* 0.013$ & 0.62 & 1.62 \\
Exchange rate & -0.029 & -0.0412 & -0.802 & 0.105 & 0.63 & 1.56 \\
\hline DW & 0.000079 & 0.381 & 6.010 & $* 0.000$ & 0.57 & 1.74 \\
KS & & 1.736 & & Sig & & $* 0.000$ \\
\hline
\end{tabular}

Note. * Significant at the $5 \%$ level.

According to Table 12, it is observed that the significance level of model is 0.000 and less than 0.05 , so the model is significant. The regression model is as follows:

$$
\begin{gathered}
\operatorname{Ln} Y=14.908+ \\
-0.262 X+0.572 C_{1.1}+0.51 C_{1.2}+0.612 C_{1.3}-0.569 C_{1.4}+0.45 C_{2.1}-0.58 C_{2.2} \\
-1.485 C_{2.3}+1.146 C_{2.4}+0.782 C_{2.5}-0.029 C_{3}+0.000079 C_{4}
\end{gathered}
$$

The results in Table 12 show that significant level of Quick ratio variable is equal to 0.208 and more than 0.05 . So, the null hypothesis was not rejected with $95 \%$ confidence $(\mathrm{Sig}=0.208>0.05)$ and can be said there is no significant correlation between firm's quick ratio and firm's trading volume. Also, about the control variables, the industry $2,3,4 \& 5$, the year $3 \& 4$ and exchange rate are statistically significant $(\operatorname{Sig}<0.05)$, that their effects was controlled and eliminated. Therefore, the research hypothesis $2 b$ is not confirmed.

Table 13. Results of hierarchical multiple regression model for $\mathrm{H}_{2 b}$

\begin{tabular}{lcc}
\hline Model & $\mathrm{R}^{2}$ & $\Delta \mathrm{R}^{2}$ \\
\hline Model 1 (including control variables) & 0.249 & 0.249 \\
Model 2 (including all independent and control variables) & 0.253 & 0.004 \\
\hline
\end{tabular}

According to Table 13, it becomes clear after elimination of control variables, quick ratio express of about 0.004 of changes in the company's trading volume. 
Table 14. Hierarchical multiple regression model coefficients for $\mathrm{H}_{2 \mathrm{c}}$

\begin{tabular}{|c|c|c|c|c|c|c|}
\hline \multirow[b]{2}{*}{ Variable } & \multicolumn{2}{|c|}{ Coefficient of $\beta$} & \multirow[b]{2}{*}{ T-statistics } & \multirow[b]{2}{*}{ P-value } & \multicolumn{2}{|c|}{ Collinearity Statistics } \\
\hline & Non-standard & Standard & & & Tolerance & VIF \\
\hline Constant value & 15.186 & --- & 42.595 & 0.000 & --- & --- \\
\hline Working capital & 0.32 & 0.235 & 4.727 & $* 0.000$ & 0.88 & 1.14 \\
\hline Year 1 & 0.561 & 0.155 & 0.892 & 0.103 & 0.68 & 1.31 \\
\hline Year 2 & 0.525 & 0.111 & 1.899 & 0.058 & 0.64 & 1.57 \\
\hline Year 3 & 0.585 & 0.123 & 2.187 & $* 0.029$ & 0.68 & 1.46 \\
\hline Year 4 & -0.546 & -0.115 & -2.175 & $* 0.030$ & 0.78 & 1.29 \\
\hline Industry 1 & 0.408 & 0.077 & 1.315 & 0.190 & 0.64 & 1.56 \\
\hline Industry 2 & -0.601 & -0.143 & -2.251 & $* 0.025$ & 0.54 & 1.85 \\
\hline Industry 3 & -1.511 & -0.189 & -3.617 & $* 0.000$ & 0.80 & 1.25 \\
\hline Industry 4 & 0.837 & 0.163 & 2.681 & $* 0.008$ & 0.58 & 1.71 \\
\hline Industry 5 & 0.691 & 0.135 & 2.287 & $* 0.023$ & 0.62 & 1.60 \\
\hline Inflation rate & -0.036 & -0.016 & -0.971 & 0.281 & 0.55 & 1.49 \\
\hline Exchange rate & 0.000074 & 0.357 & 5.798 & $* 0.000$ & 0.57 & 1.75 \\
\hline DW & 1.811 & & & Sig & $* 0.000$ & \\
\hline KS & 0.247 & & & F statistics & 13.721 & \\
\hline
\end{tabular}

Note. * Significant at the $5 \%$ level; ** Million Rials.

According to Table 14, it is observed that the significance level of model is 0.000 and less than 0.05 , so the model is significant. The regression model is as follows:

$$
\begin{gathered}
\operatorname{LnY}=15.186+0.32 X+0.561 C_{1.1}+0.525 C_{1.2}+0.585 C_{1.3}-0.546 C_{1.4}+0.408 C_{2.1}-0.601 C_{2.2} \\
-1.511 C_{2.3}+0.837 C_{2.4}+0.691 C_{2.5}-0.036 C_{3}+0.000074 C_{4}
\end{gathered}
$$

The results in Table 14 show that significant level of Working capital variable is equal to 0.000 and less than 0.05 . So, the null hypothesis was rejected with $95 \%$ confidence $(\mathrm{Sig}=0.000<0.05)$ and can be said Firm's working capital has significant correlation on firm's trading volume. Due to the positive coefficient on current ratio, we can say that kind of relationship is positive and direct. Assuming a constant other variables in the regression model, and the elimination of the control variables, each unit increase in working capital resulted 0.32 unit increases in the company's trading volume. Also, about the control variables, the industry $2,3,4 \& 5$, the year $3 \& 4$ and exchange rate are statistically significant ( $\operatorname{Sig}<0.05$ ), that their effects was controlled and eliminated. Therefore, the research hypothesis $2 \mathrm{c}$ is confirmed.

Table 15. Results of hierarchical multiple regression model for $\mathrm{H}_{2 \mathrm{c}}$

\begin{tabular}{lcc}
\hline Model & $\mathrm{R}^{2}$ & $\Delta \mathrm{R}^{2}$ \\
\hline Model 1 (including control variables) & 0.249 & 0.249 \\
Model 2 (including all independent and control variables) & 0.297 & 0.048 \\
\hline
\end{tabular}

According to Table 15, it becomes clear after elimination of control variables, working capital express of about 0.048 of changes in the company's trading volume. 
Table 16. Hierarchical multiple regression model coefficients for $\mathrm{H}_{2 \mathrm{~d}}$

\begin{tabular}{lcccccc}
\hline & \multicolumn{2}{c}{ Coefficient of $\beta$} & & & \multicolumn{2}{c}{ Collinearity Statistics } \\
\cline { 2 - 3 } Variable & Non-standard & Standard & T-statistics & P-value & Tolerance & VIF \\
\hline Constant value & 15.206 & -- & 41.066 & 0.000 & -- & -- \\
Operating cash flow & -0.492 & -0.101 & -1.803 & 0.072 & 0.73 & 1.37 \\
Year 1 & 0.306 & 0.201 & 1.21 & 0.094 & 0.7 & 1.29 \\
Year 2 & 0.518 & 0.109 & 1.819 & 0.070 & 0.64 & 1.57 \\
Year 3 & 0.583 & 0.123 & 2.115 & $* 0.035$ & 0.68 & 1.47 \\
Year 4 & -0.601 & -0.127 & -2.327 & $* 0.021$ & 0.78 & 1.29 \\
Industry 1 & 0.472 & 0.089 & 1.436 & 0.152 & 0.60 & 1.66 \\
Industry 2 & -0.549 & -0.13 & -1.997 & $* 0.047$ & 0.54 & 1.86 \\
Industry 3 & -1.584 & -0.198 & -3.683 & $* 0.000$ & 0.80 & 1.26 \\
Industry 4 & 1.47 & 0.287 & 4.306 & $* 0.000$ & 0.52 & 1.93 \\
Industry 5 & 0.719 & 0.14 & 2.312 & $* 0.021$ & 0.62 & 1.60 \\
Inflation rate & -0.038 & -0.019 & -0.881 & 0.215 & 0.63 & 1.87 \\
Exchange rate & 0.00008 & 0.389 & 6.166 & $* 0.000$ & 0.58 & 1.73 \\
DW & & & & Sig & & $* 0.000$
\end{tabular}

Note. * Significant at the $5 \%$ level.

According to Table 16, it is observed that the significance level of model is 0.000 and less than 0.05 , so the model is significant. The regression model is as follows:

$$
\begin{gathered}
\operatorname{Ln} Y=15.206-0.492 X+0.306 C_{1.1}+0.518 C_{1.2}+0.583 C_{1.3}-0.601 C_{1.4}+0.472 C_{2.1}-0.549 C_{2.2} \\
-1.584 C_{2.3}+1.47 C_{2.4}+0.719 C_{2.5}-0.038 C_{3}+0.00008 C_{4}
\end{gathered}
$$

The results in Table 16 show that significant level of Operating cash flow variable is equal to 0.072 and more than 0.05 . So, the null hypothesis was not rejected with 95\% confidence ( $\mathrm{Sig}=0.072>0.05$ ) and can be said there is no significant correlation between firm's operating cash flow and firm's trading volume. Also, about the control variables, the industry $2,3,4 \& 5$, the year $3 \& 4$ and exchange rate are statistically significant $(\operatorname{Sig}<0.05)$, that their effects was controlled and eliminated. Therefore, the research hypothesis $2 \mathrm{~d}$ is not confirmed.

Table 17. Results of hierarchical multiple regression model for $\mathrm{H}_{2 \mathrm{~d}}$

\begin{tabular}{lcc}
\hline Model & $\mathrm{R}^{2}$ & $\Delta \mathrm{R}^{2}$ \\
\hline Model 1 (including control variables) & 0.249 & 0.249 \\
Model 2 (including all independent and control variables) & 0.257 & 0.007 \\
\hline
\end{tabular}

According to Table 17, it becomes clear after elimination of control variables, operating cash flow express of about 0.007 of changes in the company's trading volume.

Consequently, according to the results of hypothesis testing, it was determined that Current ratio and Working capital have a significant relationship with trading volume. So considering that two of the four Liquidity indicators have a significant relationship with trading volume, so we can say that generally the second research hypothesis is confirmed.

\subsection{The Third Hypothesis Testing $\left(H_{3}\right)$}

This hypothesis includes the 5 Secondary hypotheses. First, we test the Secondary hypothesises and then final conclusions expressed based on the results. Hierarchical multiple regression results are shown in the following tables. 
Table 18. Hierarchical multiple regression model coefficients for $\mathrm{H}_{3 \mathrm{a}}$

\begin{tabular}{|c|c|c|c|c|c|c|}
\hline \multirow[b]{2}{*}{ Variable } & \multicolumn{2}{|c|}{ Coefficient of $\beta$} & \multirow[b]{2}{*}{ T-statistics } & \multirow[b]{2}{*}{ P-value } & \multicolumn{2}{|c|}{ Collinearity Statistics } \\
\hline & Non-standard & Standard & & & Tolerance & VIF \\
\hline Constant value & 15.142 & --- & 29.936 & 0.000 & --- & --- \\
\hline Debt to assets & -0.051 & -0.005 & -0.093 & 0.926 & 0.81 & 1.24 \\
\hline Year 1 & 0.209 & 0.281 & 1.07 & 0.104 & 0.62 & 1.68 \\
\hline Year 2 & 0.518 & 0.109 & 1.809 & 0.071 & 0.64 & 1.57 \\
\hline Year 3 & 0.62 & 0.131 & 2.242 & $* 0.026$ & 0.68 & 1.47 \\
\hline Year 4 & -0.584 & -0.123 & -2.251 & $* 0.025$ & 0.78 & 1.29 \\
\hline Industry 1 & 0.329 & 0.062 & 1.028 & 0.305 & 0.64 & 1.56 \\
\hline Industry 2 & -0.571 & -0.136 & -2.067 & $* 0.040$ & 0.54 & 1.86 \\
\hline Industry 3 & -1.545 & -0.193 & -3.522 & $* 0.000$ & 0.77 & 1.29 \\
\hline Industry 4 & 1.206 & 0.235 & 3.701 & $* 0.000$ & 0.57 & 1.75 \\
\hline Industry 5 & 0.738 & 0.144 & 2.357 & $* 0.019$ & 0.62 & 1.61 \\
\hline Inflation rate & -0.035 & -0.023 & -0.910 & 0.113 & 0.74 & 1.25 \\
\hline Exchange rate & 0.00008 & 0.386 & 6.074 & $* 0.000$ & 0.57 & 1.75 \\
\hline DW & & 1.719 & & Sig & \multicolumn{2}{|c|}{$* 0.000$} \\
\hline KS & & 0.102 & & F statistics & \multicolumn{2}{|c|}{10.746} \\
\hline
\end{tabular}

Note. * Significant at the $5 \%$ level.

According to Table 18, it is observed that the significance level of model is 0.000 and less than 0.05 , so the model is significant. The regression model is as follows:

$$
\begin{gathered}
\operatorname{Ln} Y=15.142-0.501 X+0.209 C_{1.1}+0.518 C_{1.2}+0.62 C_{1.3}-0.584 C_{1.4}+0.329 C_{2.1}-0.571 C_{2.2} \\
-1.545 C_{2.3}+1.206 C_{2.4}+0.738 C_{2.5}-0.035 C_{3}+0.00008 C_{4}
\end{gathered}
$$

The results in Table 18 show that significant level of debt to assets ratio variable is equal to 0.926 and more than 0.05 . So, the null hypothesis was not rejected with $95 \%$ confidence $(\mathrm{Sig}=0.926>0.05)$ and can be said there is no significant correlation between firm's debt to assets ratio and firm's trading volume. Also, about the control variables, the industry $2,3,4 \& 5$, the year $3 \& 4$ and exchange rate are statistically significant $(\operatorname{Sig}<0.05)$, that their effects was controlled and eliminated. Therefore, the research hypothesis $3 \mathrm{a}$ is not confirmed.

Table 19. Results of hierarchical multiple regression model for $\mathrm{H}_{3 a}$

\begin{tabular}{lcc}
\hline Model & $\mathrm{R}^{2}$ & $\Delta \mathrm{R}^{2}$ \\
\hline Model 1 (including control variables) & 0.2490 & 0.2490 \\
Model 2 (including all independent and control variables) & 0.2491 & 0.0001 \\
\hline
\end{tabular}

According to Table 19, it becomes clear after elimination of control variables, debt to assets ratio express of about 0.0001 of changes in the company's trading volume.

\begin{tabular}{|c|c|c|c|c|c|c|}
\hline \multirow{2}{*}{ Variable } & \multicolumn{2}{|c|}{ Coefficient of $\beta$} & \multirow{2}{*}{ T-statistics } & \multirow{2}{*}{ P-value } & \multicolumn{2}{|c|}{ Collinearity Statistics } \\
\hline & Non-standard & Standard & & & Tolerance & VIF \\
\hline Constant value & 15.092 & --- & 41.107 & 0.000 & --- & --- \\
\hline Debt to equity & 0.004 & 0.074 & 1.496 & 0.136 & 0.95 & 1.05 \\
\hline Year 1 & 0.157 & 0.103 & 0.234 & 0.251 & 0.75 & 1.29 \\
\hline Year 2 & 0.52 & 0.11 & 1.826 & 0.069 & 0.64 & 1.57 \\
\hline Year 3 & 0.623 & 0.131 & 2.261 & $* 0.024$ & 0.68 & 1.46 \\
\hline Year 4 & -0.548 & -0.115 & -2.108 & $* 0.036$ & 0.77 & 1.30 \\
\hline
\end{tabular}

Table 20. Hierarchical multiple regression model coefficients for $\mathrm{H}_{3 \mathrm{~b}}$ 


\begin{tabular}{lcccccc}
\hline Industry 1 & 0.347 & 0.065 & 1.086 & 0.278 & 0.64 & 1.56 \\
Industry 2 & -0.572 & -0.136 & -2.080 & $* 0.038$ & 0.54 & 1.85 \\
Industry 3 & -1.437 & -0.179 & -3.285 & $* 0.001$ & 0.77 & 1.29 \\
Industry 4 & 1.219 & 0.238 & 3.916 & $* 0.000$ & 0.62 & 1.60 \\
Industry 5 & 0.734 & 0.143 & 2.358 & $* 0.019$ & 0.62 & 1.60 \\
Inflation rate & -0.022 & -0.015 & -0.776 & 0.241 & 0.66 & 1.23 \\
Exchange rate & 0.00008 & 0.387 & 6.133 & $* 0.000$ & 0.58 & 1.73 \\
\hline DW & & 1.718 & Sig & & $* 0.000$ \\
KS & & & & F statistics & & 11.043 \\
\hline
\end{tabular}

Note. * Significant at the $5 \%$ level.

According to Table 20, it is observed that the significance level of model is 0.000 and less than 0.05 , so the model is significant. The regression model is as follows:

$$
\begin{gathered}
\operatorname{LnY}=15.092+0.004 X+0.157 C_{1.1}+0.52 C_{1.2}+0.623 C_{1.3}-0.548 C_{1.4}+0.347 C_{2.1}-0.572 C_{2.2} \\
-1.437 C_{2.3}+1.219 C_{2.4}+0.734 C_{2.5}-0.022 C_{3}+0.00008 C_{4}
\end{gathered}
$$

The results in Table 20 show that significant level of debt to equity ratio variable is equal to 0.136 and more than 0.05 . So, the null hypothesis was not rejected with $95 \%$ confidence $(\mathrm{Sig}=0.136>0.05)$ and can be said there is no significant correlation between firm's debt to equity ratio and firm's trading volume. Also, about the control variables, the industry $2,3,4 \& 5$, the year $3 \& 4$ and exchange rate are statistically significant $(\operatorname{Sig}<0.05)$, that their effects was controlled and eliminated. Therefore, the research hypothesis $3 \mathrm{~b}$ is not confirmed.

Table 21. Results of hierarchical multiple regression model for $\mathrm{H}_{3 \mathrm{~b}}$

\begin{tabular}{lcc}
\hline Model & $\mathrm{R}^{2}$ & $\Delta \mathrm{R}^{2}$ \\
\hline Model 1 (including control variables) & 0.249 & 0.249 \\
Model 2 (including all independent and control variables) & 0.254 & 0.005 \\
\hline
\end{tabular}

According to Table 21, it becomes clear after elimination of control variables, debt to equity ratio express of about 0.005 of changes in the company's trading volume.

\begin{tabular}{|c|c|c|c|c|c|c|}
\hline \multirow{2}{*}{ Variable } & \multicolumn{2}{|c|}{ Coefficient of $\beta$} & \multirow{2}{*}{ T-statistics } & \multirow{2}{*}{ P-value } & \multicolumn{2}{|c|}{ Collinearity Statistics } \\
\hline & Non-standard & Standard & & & Tolerance & VIF \\
\hline Constant value & 15.121 & --- & 41.102 & 0.000 & --- & --- \\
\hline Plant assets to long-term liabilities & 0.001 & 0.043 & 0.889 & 0.375 & 0.97 & 1.03 \\
\hline Year 1 & 0.204 & 0.161 & 0.412 & 0.325 & 0.73 & 1.02 \\
\hline Year 2 & 0.578 & 0.121 & 2.022 & $* 0.044$ & 0.64 & 1.57 \\
\hline Year 3 & 0.604 & 0.127 & 2.189 & $* 0.029$ & 0.68 & 1.46 \\
\hline Year 4 & -0.602 & -0.127 & -2.317 & $* 0.021$ & 0.77 & 1.30 \\
\hline Industry 1 & 0.317 & 0.06 & 0.984 & 0.326 & 0.63 & 1.59 \\
\hline Industry 2 & -0.593 & -0.142 & -2.137 & $* 0.033$ & 0.52 & 1.91 \\
\hline Industry 3 & -1.572 & -0.198 & -3.666 & $* 0.000$ & 0.79 & 1.27 \\
\hline Industry 4 & 1.423 & 0.27 & 4.417 & $* 0.000$ & 0.62 & 1.62 \\
\hline Industry 5 & 0.717 & 0.141 & 2.294 & $* 0.022$ & 0.61 & 1.65 \\
\hline Inflation rate & -0.036 & -0.028 & -0.998 & 0.519 & 0.71 & 1.06 \\
\hline Exchange rate & & 0.385 & 6.084 & $* 0.000$ & 0.57 & 1.74 \\
\hline DW & & 1.767 & & Sig & & \\
\hline KS & & 0.111 & & F statistics & & \\
\hline
\end{tabular}

Table 22. Hierarchical multiple regression model coefficients for $\mathrm{H}_{3 \mathrm{c}}$

Note. * Significant at the $5 \%$ level. 
According to Table 22, it is observed that the significance level of model is 0.000 and less than 0.05 , so the model is significant. The regression model is as follows:

$$
\begin{gathered}
\operatorname{Ln} Y=15.121+0.001 X+0.204 C_{1.1}+0.578 C_{1.2}+0.604 C_{1.3}-0.602 C_{1.4}+0.317 C_{2.1}-0.593 C_{2.2} \\
-1.572 C_{2.3}+1.423 C_{2.4}+0.717 C_{2.5}-0.036 C_{3}+0.00008 C_{4}
\end{gathered}
$$

The results in Table 22 show that significant level of plant assets to long-term liabilities variable is equal to 0.375 and more than 0.05 . So, the null hypothesis was not rejected with $95 \%$ confidence ( $\mathrm{Sig}=0.375>0.05$ ) and can be said there is no significant correlation between firm's plant assets to long-term liabilities and firm's trading volume. Also, about the control variables, the industry 2, 3, $4 \& 5$, the year $3 \& 4$ and exchange rate are statistically significant $(\mathrm{Sig}<0.05)$, that their effects was controlled and eliminated. Therefore, the research hypothesis $3 \mathrm{c}$ is not confirmed.

Table 23. Results of hierarchical multiple regression model for $\mathrm{H}_{3 \mathrm{c}}$

\begin{tabular}{lll}
\hline Model & $\mathrm{R}^{2}$ & $\Delta \mathrm{R}^{2}$ \\
\hline Model 1 (including control variables) & 0.249 & 0.249 \\
Model 2 (including all independent and control variables) & 0.278 & 0.002 \\
\hline
\end{tabular}

According to Table 23, it becomes clear after elimination of control variables, Plant assets to long-term liabilities express of about 0.002 of changes in the company's trading volume.

\begin{tabular}{|c|c|c|c|c|c|c|}
\hline \multirow[b]{2}{*}{ Variable } & \multicolumn{2}{|c|}{ Coefficient of $\beta$} & \multirow[b]{2}{*}{ T-statistics } & \multirow[b]{2}{*}{ P-value } & \multicolumn{2}{|c|}{ Collinearity Statistics } \\
\hline & Non-standard & Standard & & & Tolerance & VIF \\
\hline Constant value & 15.221 & --- & 41.271 & 0.000 & --- & --- \\
\hline Cash flow to total debt & -0.691 & -0.124 & -2.233 & $* 0.026$ & 0.74 & 1.36 \\
\hline Year 1 & 0.216 & 0.223 & 0.291 & 0.193 & 0.66 & 1.52 \\
\hline Year 2 & 0.514 & 0.108 & 1.810 & 0.071 & 0.64 & 1.57 \\
\hline Year 3 & 0.577 & 0.122 & 2.100 & $* 0.037$ & 0.68 & 1.47 \\
\hline Year 4 & -0.612 & -0.129 & -2.376 & $* 0.018$ & 0.77 & 1.29 \\
\hline Industry 1 & 0.456 & 0.086 & 1.411 & 0.159 & 0.62 & 1.61 \\
\hline Industry 2 & -0.54 & -0.128 & -1.969 & $* 0.050$ & 0.54 & 1.86 \\
\hline Industry 3 & -1.589 & -0.198 & -3.704 & $* 0.000$ & 0.80 & 1.26 \\
\hline Industry 4 & 1.537 & 0.3 & 4.496 & $* 0.000$ & 0.51 & 1.95 \\
\hline Industry 5 & 0.712 & 0.139 & 2.297 & $* 0.022$ & 0.62 & 1.60 \\
\hline Inflation rate & -0.033 & -0.021 & -0.559 & 0.196 & 0.61 & 1.92 \\
\hline Exchange rate & 0.00008 & 0.392 & 6.228 & $* 0.000$ & 0.58 & 1.73 \\
\hline DW & & 1.729 & & Sig & & \\
\hline KS & & 0.317 & & F statistics & & \\
\hline
\end{tabular}

Table 24. Hierarchical multiple regression model coefficients for $\mathrm{H}_{3 \mathrm{~d}}$

Note. * Significant at the $5 \%$ level.

According to Table 24, it is observed that the significance level of model is 0.000 and less than 0.05 , so the model is significant. The regression model is as follows:

$$
\begin{gathered}
\operatorname{Ln} Y=15.221-0.691 X+0.216 C_{1.1}+0.514 C_{1.2}+0.577 C_{1.3}-0.612 C_{1.4}+0.456 C_{2.1}-0.54 C_{2.2} \\
-1.589 C_{2.3}+1.537 C_{2.4}+0.712 C_{2.5}-0.033 C_{3}+0.00008 C_{4}
\end{gathered}
$$

The results in Table 24 show that significant level of cash flow to total debt variable is equal to 0.026 and less than 0.05 . So, the null hypothesis was rejected with $95 \%$ confidence ( $\mathrm{Sig}=0.026<0.05$ ) and can be said Firm's 
cash flow to total debt has significant correlation on firm's trading volume. Due to the negative coefficient on current ratio, we can say that kind of relationship is negative and reverse. Assuming a constant other variables in the regression model, and the elimination of the control variables, each unit increase in cash flow to total debt resulted 0.691 unit decreases in the company's trading volume. Also, about the control variables, the industry 2, $3,4 \& 5$, the year $3 \& 4$ and exchange rate are statistically significant $(\mathrm{Sig}<0.05)$, that their effects was controlled and eliminated. Therefore, the research hypothesis $3 \mathrm{~d}$ is confirmed.

Table 25. Results of hierarchical multiple regression model for $\mathrm{H}_{3 \mathrm{~d}}$

\begin{tabular}{lcc}
\hline Model & $\mathrm{R}^{2}$ & $\Delta \mathrm{R}^{2}$ \\
\hline Model 1 (including control variables) & 0.249 & 0.249 \\
Model 2 (including all independent and control variables) & 0.260 & 0.011 \\
\hline
\end{tabular}

According to Table 25, it becomes clear after elimination of control variables, Cash flow to total debt express of about 0.011 of changes in the company's trading volume.

Table 26. Hierarchical multiple regression model coefficients for $\mathrm{H}_{3 \mathrm{e}}$

\begin{tabular}{|c|c|c|c|c|c|c|}
\hline \multirow[b]{2}{*}{ Variable } & \multicolumn{2}{|c|}{ Coefficient of $\beta$} & \multirow[b]{2}{*}{ T-statistics } & \multirow[b]{2}{*}{ P-value } & \multicolumn{2}{|c|}{ Collinearity Statistics } \\
\hline & Non-standard & Standard & & & Tolerance & VIF \\
\hline Constant value & 15.093 & --- & 35.983 & 0.000 & --- & --- \\
\hline Equity financing ratio & 0.045 & 0.004 & 0.082 & 0.934 & 0.81 & 1.24 \\
\hline Year 1 & 0.101 & 0.204 & 0.117 & 0.341 & 0.80 & 1.26 \\
\hline Year 2 & 0.518 & 0.109 & 1.809 & 0.071 & 0.64 & 1.57 \\
\hline Year 3 & 0.621 & 0.131 & 2.242 & $* 0.026$ & 0.68 & 1.47 \\
\hline Year 4 & -0.584 & -0.123 & -2.251 & $* 0.025$ & 0.78 & 1.29 \\
\hline Industry 1 & 0.329 & 0.062 & 1.028 & 0.305 & 0.64 & 1.56 \\
\hline Industry 2 & -0.571 & -0.136 & -2.068 & *0.039 & 0.54 & 1.86 \\
\hline Industry 3 & -1.546 & -0.193 & -3.524 & $* 0.000$ & 0.77 & 1.29 \\
\hline Industry 4 & 1.207 & 0.236 & 3.704 & $* 0.000$ & 0.57 & 1.75 \\
\hline Industry 5 & 0.738 & 0.144 & 2.356 & $* 0.019$ & 0.62 & 1.61 \\
\hline Inflation rate & -0.039 & -0.027 & -0.339 & 0.281 & 0.57 & 1.60 \\
\hline Exchange rate & 0.00008 & 0.386 & 6.073 & $* 0.000$ & 0.57 & 1.75 \\
\hline DW & & 1.719 & & Sig & $* 0.0$ & \\
\hline KS & & 0.101 & & F statistics & 10.7 & \\
\hline
\end{tabular}

Note. * Significant at the $5 \%$ level.

According to Table 26, it is observed that the significance level of model is 0.000 and less than 0.05 , so the model is significant. The regression model is as follows:

$$
\begin{gathered}
\operatorname{Ln} Y=15.093+0.045 X+0.101 C_{1.1}+0.518 C_{1.2}+0.621 C_{1.3}-0.584 C_{1.4}+0.329 C_{2.1}-0.571 C_{2.2} \\
-1.546 C_{2.3}+1.207 C_{2.4}+0.738 C_{2.5}-0.039 C_{3}+0.00008 C_{4}
\end{gathered}
$$

The results in Table 26 show that significant level of equity financing ratio variable is equal to 0.934 and more than 0.05 . So, the null hypothesis was not rejected with $95 \%$ confidence $(\mathrm{Sig}=0.934>0.05$ ) and can be said there is no significant correlation between firm's equity financing ratio and firm's trading volume. Also, about the control variables, the industry $2,3,4 \& 5$, the year $3 \& 4$ and exchange rate are statistically significant $(\mathrm{Sig}<0.05)$, that their effects was controlled and eliminated. Therefore, the research hypothesis $3 \mathrm{e}$ is not confirmed. 
Table 27. Results of hierarchical multiple regression model for $\mathrm{H}_{3 \mathrm{e}}$

\begin{tabular}{lcc}
\hline Model & $\mathrm{R}^{2}$ & $\Delta \mathrm{R}^{2}$ \\
\hline Model 1 (including control variables) & 0.249 & 0.249 \\
Model 2 (including all independent and control variables) & 0.2491 & 0.0001 \\
\hline
\end{tabular}

According to Table 27, it becomes clear after elimination of control variables, equity financing ratio express of about 0.0001 of changes in the company's trading volume.

Consequently, according to the results of hypothesis testing, it was determined that only Cash flow to total debt ratio has a significant relationship with trading volume.

\section{Conclusion and Remarks}

The results showed that the profitability was not statistically significant with trading volume. As the ratios of operating margin, return on assets and return on equity have no significant relationship with the company trading volume and just net margin affect over 0.015 on the company's stock trading volume. This result is in contrast to findings of Chu and Ip (2007).

So, the results showed that the Liquidity was statistically significant with trading volume. As the ratios of quick and operating cash flow have no significant relationship with the company trading volume but current ratio and working capital effect on the company's stock trading volume. This result is in accordance with findings of Chu and Ip (2007).

As well, the results showed that the Solvency was not statistically significant with trading volume. As the ratios of debt to assets, debt to equity, plant assets to long-term liabilities and equity financing have no significant relationship with the company trading volume and just cash flow to total debt effect on the company's stock trading volume.

Well as, the results showed that the Efficiency was statistically significant with trading volume.

\section{References}

Bissoondoyal-Bheenicka, E., \& Brooks, R. D. (2010). Does volume help in predicting stock returns? An analysis of the Australian market. Research in International Business and Finance, 24, 146-157. http://dx.doi.org/10.1016/j.ribaf.2009.11.001

Chu, A. C. L., \& Ip, C. S. F. (2007). How company information affect the short selling in the Hong Kong stock market? Retrieved December 31, 2014 from http://hdl.handle.net/2031/5123

Chuang, W., Liu, H. H., \& Susmel, R. (2012). The bivariate GARCH approach to investigating the relation between stock returns \& trading volume \& return volatility. Global Finance Journal, 23, 1-15. http://dx.doi.org/10.1016/j.gfj.2012.01.001

Clark-Murphy, M., \& Soutar, G. N. (2004). What individual investors value: Some Australian evidence. Journal of Economic Psychology, 25(4), 539-555. http://dx.doi.org/10.1016/S0167-4870(03)00056-4

Firoozi, M., Hemmati, H., \& Ghodrati, H. (2013). Assess the relationship between liquidity asset and liquidity stocks. Economics and Business, 3(1), 75-83.

Gopalan, R., Kadan, O., \& Pevzner, M. (2009). Managerial decisions: Asset liquidity, and stock liquidity. http://dx.doi.org/10.2139/ssrn.1159791

Jahankhani, A., \& Saffarian, A. (2004). The stock market reaction to the announcement of earnings per share estimate at Tehran Stock Exchange. Journal of Financial Research, 16, 61-81.

Khoshtinat, M., \& Hajian, N. (2009). The effect of increasing dividends on investment behavior. Review of Accounting and Auditing, 51, 3-18.

Lee, B. S., \& Rui, O. M. (2002). The dynamic relationship between stock returns and trading volume: Domestic and cross-country evidence. Journal of Banking \& Finance, 26, 51-78. http://dx.doi.org/10.1016/S0378-4266(00)00173-4

Lo, A. W., \& Wang, J. (2000). Trading volume: Definition, data analysis, and implication of portfolio theory. The Review of Financial Studies, 13, 257-300. http://dx.doi.org/10.1093/rfs/13.2.257

Mitchell, C. (2014). How to use volume to improve your trading. Retrieved from 
http://www.investopedia.com/articles/technical/02/010702.asp

Park, B. (2010). Surprising information \& the MDH \& the relationship between volatility and trading volume. Journal of Financial Markets, 13, 344-366. http://dx.doi.org/10.1016/j.finmar.2010.02.001

Purebrahimi, M., \& Seyedkhosroshahi, S. A. (2013). Relationship between the percentage of dividends and trading volume in firms listed in Tehran Stock Exchange. Journal of Financial Research, 14(2), 15-30.

Raee, R., Saranj, A., \& Sadeghi, M. (2011). Reviewed quarterly EPS stock company as a reference point and its effect on turnover. Journal of Accounting Research, 5, 26-37.

Rahmani, A., Hoseini, S. A., \& Rezapur, N. (2011). Relation between institutional ownership and liquidity in the stock. Review of Accounting and Auditing, 61, 39-54.

Shooshtarian, Z., \& Akbari, A. (2008). Effect of the capital increase from the prior right on the Tehran Stock Exchange trading volume. Humanities and Social Sciences, Shiraz University, 26(1), 95-115.

Talebnia, G., \& Zarey, M. N. Y. (2011). Examine the financial impact of trading volume on the Tehran Stock Exchange. Financial Research, 29, 79-98.

Weygandt, J. J., Kimmel, P. D., \& Kieso, D. E. (2010). Financial accounting (7th ed.). Hoboken, NJ: John Wiley \& Sons, Inc.

Ziebart, D. A. (1987). The effects of annual accounting data on stock returns and trading activity: A causal model study. Journal of the American Statistical Association, 82, 733-738. http://dx.doi.org/10.1080/01621459.1987.10478489

\section{Copyrights}

Copyright for this article is retained by the author(s), with first publication rights granted to the journal.

This is an open-access article distributed under the terms and conditions of the Creative Commons Attribution license (http://creativecommons.org/licenses/by/3.0/). 